\title{
Alternative Oral Mucous Membrane Pemphigoid Therapy Using Tacrolimus: A Case Report
}

\author{
Terapia Alternativa para el Penfigoide de la Membrana \\ Mucosa Oral con Tacrolimus: Reporte de un Caso
}

\author{
Caio César da Silva Barros"; Israel Leal Cavalcante ${ }^{2}$; Rafaella Bastos Leite ${ }^{3}$; Éricka Janine Dantas da Silveira1; \\ Ana Miryam Costa de Medeiros ${ }^{1} \&$ Patricia Teixeira de Oliveira ${ }^{1}$
}

BARROS, C. C. S.; CAVALCANTE, I. L.; LEITE, B. R.; DA SILVEIRA, É. J. D.; MEDEIROS, A. M. C. \& OLIVEIRA, P. T. Alternative oral mucous membrane pemphigoid therapy using tacrolimus: A case report. Int. J. Odontostomat., 15(4):904$907,2021$.

ABSTRACT: Mucous membrane pemphigoid (MMP) is a blistering disease that predominantly involves the mucous membranes and that can lead to major negative impacts on patient quality of life. The first-line MMP treatment is based on the use of topical and systemic corticosteroids. In this report, we presented a 45-year-old female patient presented blisters in the inferior gingiva for over 8-months. The patient reported being allergic to corticosteroids. Under the clinical hypothesis of oral lichen planus and MMP, an incisional biopsy was performed, and the histopathological diagnosis of MMP was established. Thus, it was instituted an alternative therapy with tacrolimus $0.03 \%$. The patient showed an excellent clinical outcome with no recurrence five months after the end of therapy. Tacrolimus $0.03 \%$ may represent an effective therapeutic alternative in MMP treatment and may be used in cases of hypersensitivity to standard therapy.

KEY WORDS: autoimmune; mucous membrane pemphigoid; calcineurin inhibitors; tacrolimus; therapy.

\section{INTRODUCTION}

Mucous membrane pemphigoid (MMP) is an autoimmune mucocutaneous disorder characterized by the appearance of blisters on the mucous membranes and skin (Arduino et al., 2017). Its pathogenesis is complex and poorly understood. However, it is known that it consists in the production of autoantibodies directed to several basal membrane components, such as collagen VII and XVII, laminin 5 and a6/b4 integrin, which results in the formation of subepidermal blisters (Xu et al., 2013; Kamaguchi \& Iwata, 2019).

The true MMP incidence is unknown, although it has been reported that this disorder affects individuals between 60 and 80 years old, predominantly women, with a male to female ratio of $2: 1$, without racial or geographical predilection (Xu et al.; Santi et al., 2019). The oral mucosa is the most prevalent region, accounting for 80 to $90 \%$ of all cases, followed by the ocular mucosa (50 \%), nasal mucosa (20-40 \%) and skin $(25-30 \%)$. In the oral cavity, the gingiva (70 \%), jugal mucosa (60 \%) and palate $(27 \%)$ are the most affected anatomicalsites (Kourosh \& Yancey, 2011; Kamaguchi \& Iwata).

MMP exhibit considerable variability in clinical presentations, where lesions may manifest as erythema, erosion, pseudomembranes, scaly gingivitis, occasional scarring, blisters, and/or vesicles (Xu et al.; Arduino et al.). Its diagnosis is based on clinical information and complementary exams, such as histopathological and/or immunological analyses. Histopathological assessments indicate the formation of a subepithelial cleft, while connective tissue exhibits inflammatory infiltrates that may consist of lymphocytes, eosinophils, and neutrophils (Lee et al., 2011; Kamaguchi \& Iwata).

\footnotetext{
${ }^{1}$ Postgraduate Program in Dental Science, Department of Dentistry, Federal University of Rio Grande do Norte, Natal, RN, Brazil.

${ }^{2}$ Department of Dentistry, University of Fortaleza, Fortaleza, CE, Brazil.

${ }^{3}$ Federal University of Rio Grande do Norte, Natal, RN, Brazil.
} 
A multidisciplinary approach is often required, where the main treatment goals are to improve symptomatology, interrupt disease progression and prevent chronic inflammatory process sequelae and tissue scarring. The first-line MMP treatment is based on the use of topical and systemic corticosteroids, such as prednisone, clobetasol propionate and betamethasone dipropionate (Xu et al.; Santi et al.). This study aims to report a clinical case of MMP in which the patient was allergic to corticosteroid therapy and discuss important aspects regarding the treatment of this condition.

\section{CASE REPORT}

A 45-year-old female patient was received at the Dentistry Department Oral Medicine Service complaining of painful blisters with an 8-month evolution in the lower gingiva. Regarding previous medical history, the patient reported being hypertensive, depressive, and allergic to corticosteroids. An intraoral examination revealed an erythematous lesion with an

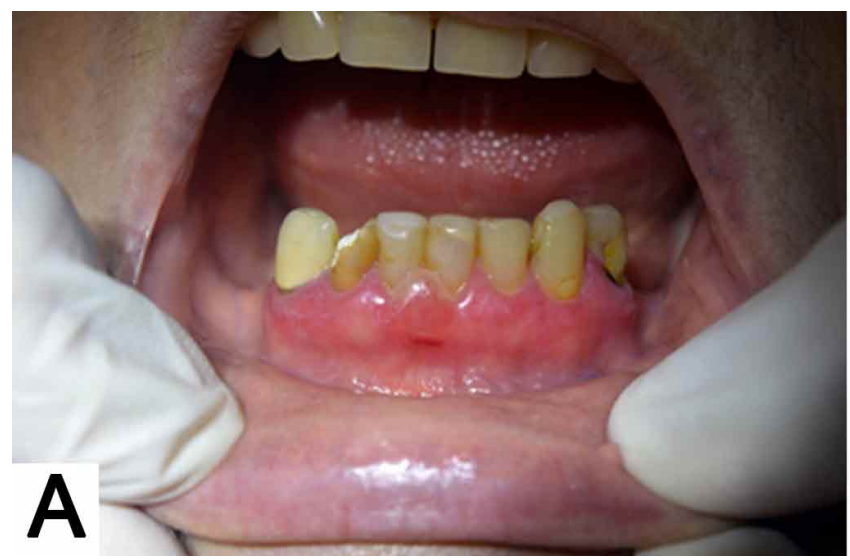

ulcerated area measuring approximately $0.4 \mathrm{~cm}$ in the anterior inferior inserted gingiva (Fig. 1A). One week after the first clinical visit, a gingival blister appeared in the lower lingual region, close to tooth 41 (Fig. 1B).

The clinical hypotheses of oral lichen planus and MMP were instituted and an incisional biopsy was performed. A histopathological examination revealed the presence of paraceratinized stratified squamous epithelium presenting acanthosis and hydropic degeneration areas (Fig. 2A) completely detached from connective tissue. Additionally, dense fibrous connective tissue exhibited diffuse chronic inflammatory infiltrates (Fig. 2B). The clinical and histopathological information led to the final MMP diagnosis and the patient was referred to an ophthalmologist, who reported no ocular changes.

Due to the allergic condition to corticosteroids, treatment with tacrolimus $0.03 \%$ (carboxymethyl cellulose gel) was instituted, applied with the aid of a whitening tray (Fig. 3A). The initial treatment protocol consisted of a test in which the drug was used once a day for five minutes for a week, in order to assess any

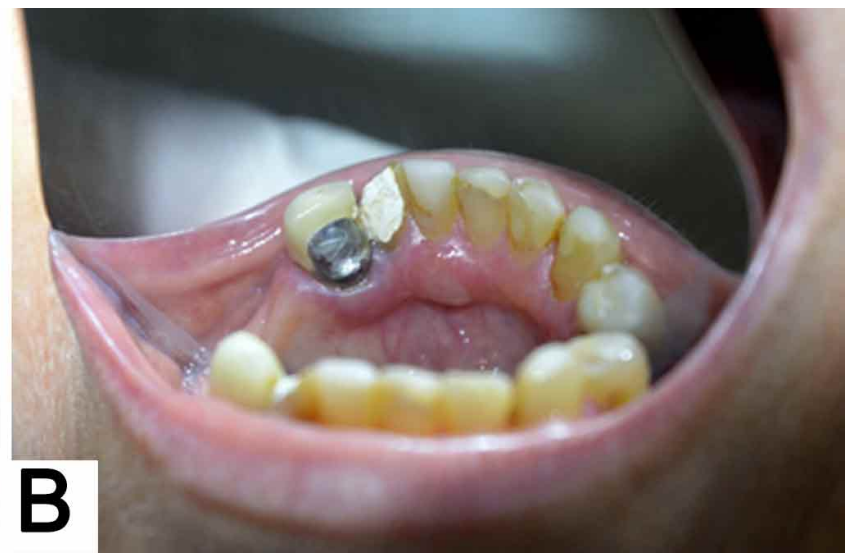

Fig. 1. Intraoral clinical aspect - (A) Erythematous lesion with an ulcerated area in the anterior inferior gingiva. (B) Gingival blister in the lower lingual region close to tooth 41.
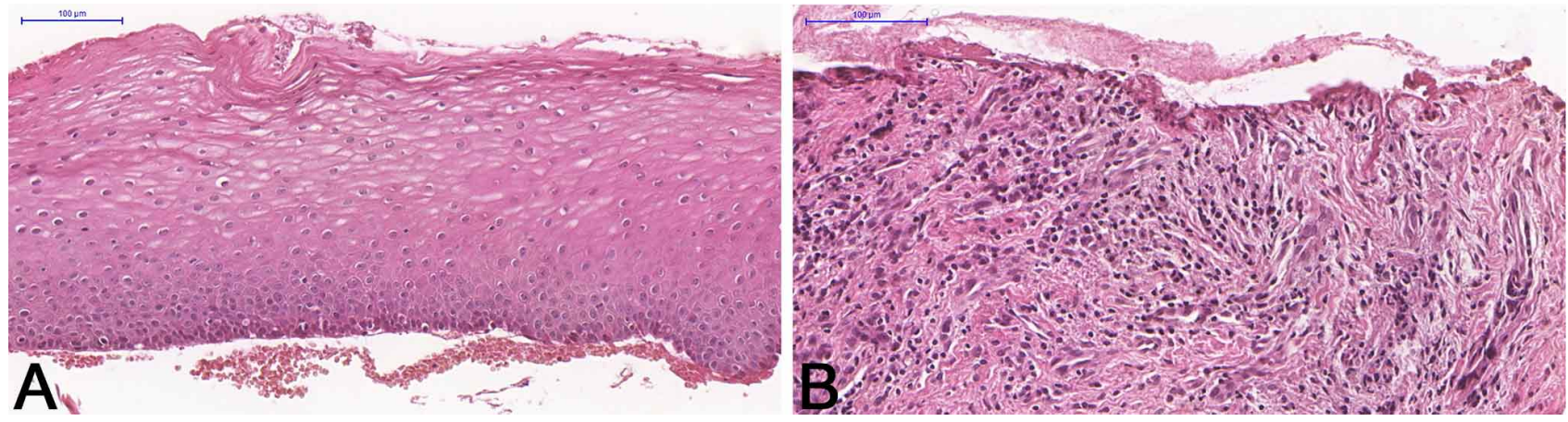

Fig. 2. Histopathological features (Hematoxylin and Eosin) - (A - $100 \mu \mathrm{m})$ Paraceratinized stratified squamous epithelium completely detached from connective tissue. $(B-100 \mu \mathrm{m})$ Connective tissue exhibited diffuse chronic inflammatory infiltrates. 

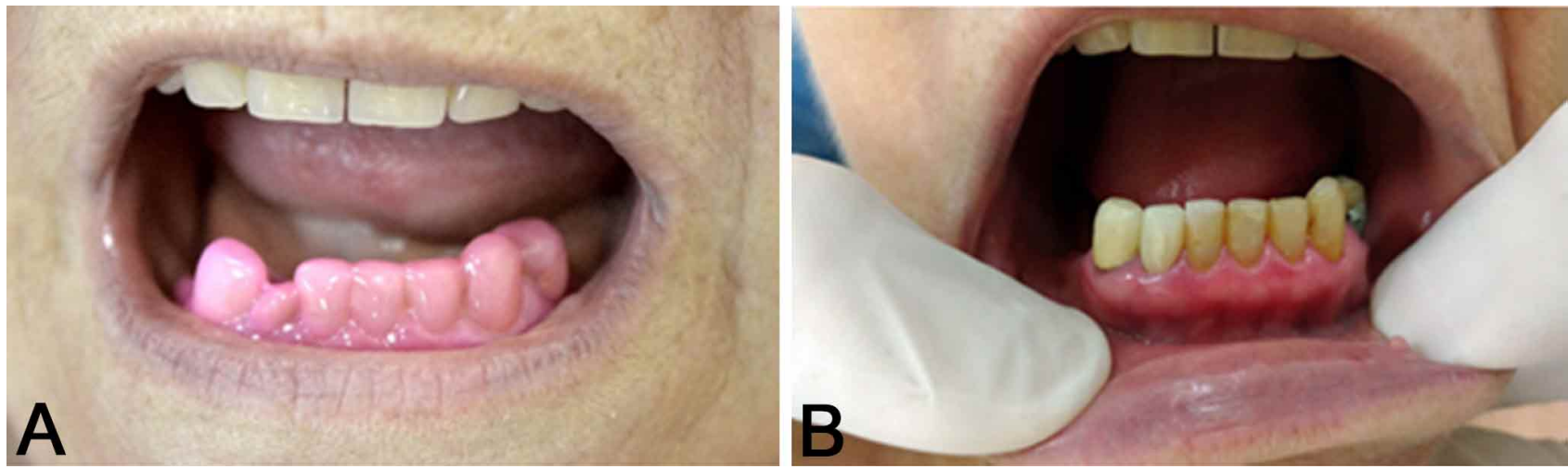

Fig. 3. (A) Tacrolimus application with the aid of a whitening tray.(B)Final intraoral clinical aspect with no recurrence five months after the end of therapy.

adverse reactions. Subsequently, during the first treatment stage, applications were performed twice a day for twenty minutes for 45 days. During the second stage, applications were reduced to once a day, following the same time and period as the previous stage. The clinical scenario improved during the first stage of treatment, and no new lesions were observed up to five months after the end of therapy (Fig. 3B).

\section{DISCUSSION}

MMP is a chronic and progressive condition that can lead to major negative impacts on patient quality of life. Its inflammatory nature promotes tissue destruction and scarring, which often results in disabling sequelae (Lee et al.; Witte et al., 2018). Its therapy is established from clinical lesion features, such as size, progression, severity, and location (Neff et al., 2008).

Clinically, patients may be classified as low risk, when lesions are restricted to the oral mucosa, or high risk, where ocular, pharyngeal, laryngeal, esophageal and/or genital mucosa manifestations of the disease are also present. Treatment for low risk cases applies a conservative approach, where topical treatment is advised. High risk cases, on the other hand, assume a more aggressive approach, using systemic drugs. However, due to the absence of randomized controlled trials, MMP therapeutic strategies are based on experiences and reports described in the literature (Chan et al., 2002; Neff et al.; Lee et al.; Santi et al.). In the present case, the patient was categorized as a low risk case because of her small and gingivalrestricted lesions. Thus, topical therapy with $0.03 \%$ tacrolimus was the treatment of choice, as the patient is allergic to corticosteroids.

Tacrolimus is a topical immunosuppressant whose mechanism of action is based on the inhibition of calcineurin, which prevents T lymphocyte activation and decreases the release of several proinflammatory cytokines (Hultsch et al., 2005; Luger \& Paul, 2007). Its use has been shown to be safe in the treatment of various conditions, such as oral lichen planus, oral manifestations of graft-versus-host disease, and pemphigus vulgaris. It appears to be well tolerated when in contact with oral mucous membranes, leading to no adverse effects and/or complications associated with systemic immunosuppression (Hultsch et al.; Lee et al., 2011). This was proven herein, since the patient did not exhibit any drug sensitivity during the treatment.

Although no established therapeutic protocol is available, the literature reports that topical tacrolimus should initially be applied twice daily, according to patient tolerance (Suresh et al., 2006; Lee et al.; Santi et al.). Regarding the present case, the patient first applied tacrolimus $0.03 \%$ twice a day, with the aid of a whitening tray, to maintain direct drug contact with the lesions. Later, due to decreased lesion size and number, the patient was advised to reduce its use to once a day.

In the present case, the patient displayed clinical improvement during the first treatment stage, with no recurrence five months after treatment conclusion. This corroborates literature reports that point out that tacrolimus seems to be more effective for the treatment of lesions restricted to the oral cavity, which show complete remission within 2 to 3 months of treatment (Hultsch et al.; Suresh et al.; Santi et al.). 


\section{CONCLUSION}

Thus, tacrolimus $0.03 \%$ may represent an effective therapeutic alternative in MMP treatment in low risk patients and may be used in cases of hypersensitivity to standard therapy or applied alternately, in order to reduce the risk of long-term corticosteroid side effects. In addition, long-term follow-up should be performed to detect the early onset of new lesions and possible involvement of other mucous membranes.

BARROS, C. C. S.; CAVALCANTE, I. L.; LEITE, B. R.; DA SILVEIRA, É. J. D.; MEDEIROS, A. M. C. \& OLIVEIRA, P. T. Terapia alternativa para el penfigoide de la membrana mucosa oral con tacrolimus: Reporte de un caso. Int. J. Odontostomat., 15(4):904-907, 2021.

RESUMEN: El penfigoide de la membrana mucosa (PMM) es una enfermedad ampollosa que afecta predominantemente a las membranas mucosas y que puede provocar importantes impactos negativos en la calidad de vida del paciente. El tratamiento de primera línea de PMM se basa en el uso de corticosteroides tópicos y sistémicos. En este informe, presentamos un caso de una paciente femenina de 45 años que presentó ampollas en la encía inferior durante más de 8 meses. La paciente informó ser alérgica a los corticosteroides. Bajo la hipótesis clínica de liquen plano oral y PMM, se realizó una biopsia incisional y se estableció el diagnóstico histopatológico de PMM. Por lo tanto, se instituyó una terapia alternativa con tacrolimus tópico al 0,03\%. La paciente mostró un excelente resultado clínico sin recurrencia después de 5 meses de la terapia final. Tacrolimus $0,03 \%$ puede representar una alternativa terapéutica efectiva en el tratamiento de PMM y se puede usar en casos de hipersensibilidad a la terapia estándar.

PALABRAS CLAVE: autoinmune, penfigoide de la membrana mucosa, inhibidores de la calcineurina, tacrolimus, terapia.

\section{REFERENCES}

Arduino, P. G.; Broccoletti, R.; Carbone, M.; Conrotto, D.; Pettigiani, E.; Giacometti, S.; Gambino, A.; Elia, A. \& Carrozzo, M. Describing the gingival involvement in a sample of 182 Italian predominantly oral mucous membrane pemphigoid patients: A retrospective series. Med. Oral Patol. Oral Cir. Bucal, 22(2):e14952, 2017.

Chan, L. S.; Ahmed, A. R.; Anhalt, G. J.; Bernauer, W.; Cooper, K. D.; Elder, M. J.; Fine, J. D.; Foster, S.; Ghohestani, R.; Hashimoto, $\mathrm{T}$.; et al. The first international consensus on mucous membrane pemphigoid: definition, diagnostic criteria, pathogenic factors, medical treatment, and prognostic indicators. Arch. Dermatol., 138(3):370-9, 2002.
Hultsch, T.; Kapp, A. \& Spergel, J. Immunomodulation and safety of topical calcineurin inhibitors for the treatment of atopic dermatitis. Dermatology, 211 (2):174-87, 2005.

Kamaguchi, M. \& Iwata, H. The diagnosis and blistering mechanisms of mucous membrane pemphigoid. Front. Immunol., 10:34, 2019.

Kourosh, A. S. \& Yancey, K. B. Pathogenesis of mucous membrane pemphigoid. Dermatol. Clin., 29(3):479-84, 2011.

Lee, H. Y.; Blazek, C.; Beltraminelli, H. \& Borradori, L. Oral mucous membrane pemphigoid: Complete response to topical tacrolimus. Acta Derm. Venerol., 91(5):604-5, 2011.

Luger, T. \& Paul, C. Potential new indications of topical calcineurin inhibitors. Dermatology, 215(Suppl. 1):45-54, 2007.

Neff, A. G.; Turner, M. \& Mutasim, D. F. Treatment strategies in mucous membrane pemphigoid. Ther. Clin. Risk. Manag., 4(3):617-26, 2008.

Santi, C. G.; Gripp, A. C.; Roselino, A. M.; Mello, D. S.; Gordilho, J. O.; Marsillac, P. F. \& Porro, A. M. Consensus on the treatment of autoimmune bullous dermatoses: bullous pemphigoid, mucous membrane pemphigoid and epidermolysis bullosa acquisita Brazilian Society of Dermatology. An. Bras. Dermatol., 94(2 Suppl. 1):33-47, 2019

Suresh, L.; Calixto, L. E. M. \& Radfar, L. Successful treatment of mucous membrane pemphigoid with tacrolimus. Spec. Care Dentist., 26(2):66-70, 2006.

Witte, M.; Zilikens, D. \& Schmidt, E. Diagnosis of automimmune blistering diseases. Front. Med., 5:296, 2018.

Xu, H. H.; Werth, V. P.; Parisi, E. \& Sollecito, T. P. Mucous membrane pemphigoid. Dent. Clin. North Am., 57(4):611-30, 2013.

Corresponding author:

Patricia Teixeira de Oliveira

Federal University of Rio Grande do Norte

Dental Science Postgraduate Program

Av. Senador Salgado Filho, 1787

Lagoa Nova

CEP 59056-000

Natal, RN

BRAZIL

E-mail: patriciateixeira21@gmail.com 